\title{
Vapor Corrosion Program Plan
}

by

K. H. Subramanian

Westinghouse Savannah River Company

Savannah River Site

Aiken, South Carolina 29808

P. E. Zapp

This paper was prepared in connection with work done under the above contract number with the U. S.

Department of Energy. By acceptance of this paper, the publisher and/or recipient acknowledges the U. S.

Government's right to retain a nonexclusive, royalty-free license in and to any copyright covering this paper, along with the right to reproduce and to authorize others to reproduce all or part of the copyrighted paper. 
This document was prepared in conjunction with work accomplished under Contract No. DE-AC09-96SR18500 with the U. S. Department of Energy.

\section{DISCLAIMER}

This report was prepared as an account of work sponsored by an agency of the United States Government. Neither the United States Government nor any agency thereof, nor any of their employees, makes any warranty, express or implied, or assumes any legal liability or responsibility for the accuracy, completeness, or usefulness of any information, apparatus, product or process disclosed, or represents that its use would not infringe privately owned rights. Reference herein to any specific commercial product, process or service by trade name, trademark, manufacturer, or otherwise does not necessarily constitute or imply its endorsement, recommendation, or favoring by the United States Government or any agency thereof. The views and opinions of authors expressed herein do not necessarily state or reflect those of the United States Government or any agency thereof.

This report has been reproduced directly from the best available copy.

Available for sale to the public, in paper, from: U.S. Department of Commerce, National Technical Information Service, 5285 Port Royal Road, Springfield, VA 22161, phone: (800) 553-6847, fax: (703) 605-6900

email: orders@ ntis.fedworld.gov

online ordering: http://www.ntis.gov/support/index.html

Available electronically at http://www.osti.gov/bridge

Available for a processing fee to U.S. Department of Energy and its contractors, in paper, from: U.S. Department of Energy, Office of Scientific and Technical Information, P.O. Box 62, Oak Ridge, TN 37831-0062,

phone: (865)576-8401,

fax: (865)576-5728

email: $\underline{\text { reports@ adonis.osti.gov }}$ 


\title{
Vapor Corrosion Program Plan
}

\author{
K. H. Subramanian
}

P.E. Zapp

Savannah River Technology Center

Strategic Materials Technology Department

Materials Technology Section

Publication Date: January 2002

DOES NOT CONTAIN

UNCLASSIFIED CONTROLLED

NUCLEAR INFORMATION

ADC \&

Reviewing

Official:

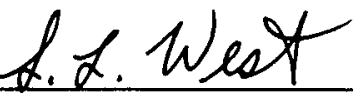

Date: $3 / 19 / 2002$

Westinghouse Savannah River Company

Savannah River Site

Aiken, SC 29808

This document was prepared in connection with work done under Contract No. DE-AC09-96SR18500

with the U. S. Department of Energy 
WSRC-TR-2002-00065.

DOCUMENT: WSRC-TR-2002-00065

TITLE: Vapor Corrosion Program Plan

APPROVALS

Ulattuth hin Date: $1 / 30 / 02$

K. H. Subramanian, Author

Materials Performance and Corrosion Technology

Materials Technology Section

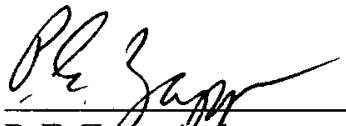

Date: $1 / 30 / 02$

P. E. Lap, Author

Materials Performance and Corrosion Technology

Materials Technology Section

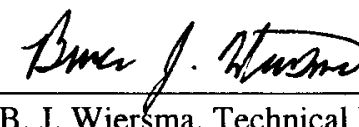

Date: $1 / 30 / 02$

B. J. Wiersma, Technical Reviewer

Materials Performance and Corrosion Technology

Materials Technology Section

Yr g.Conl Date: 1/30/02

G. T. Chandler, Manager

Materials Performance and Corrosion Technology

Materials Technology Section

1

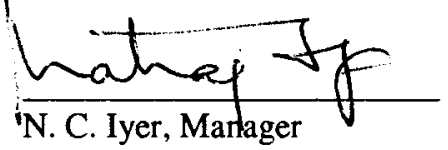

Date: $2 / 15 / 02$
Hontryancer Date: $2 / 4 / 02$

R. L. Shanks, Technical Advisor

High Level Waste Division

Concentrate, Storage, and Transfer Engineering

7 max 2 . Then $2-1-02$

T. E. Chandler, Manager

High Lefel Waste Division

Concentrate, Storage, and Transfer Engineering

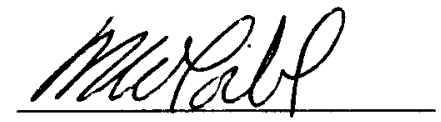

Date: $2 / 1 / / 02$

M. W. Loibl, Manager

High Level Waste Division

Concentrate, Storage, and Transfer Engineering

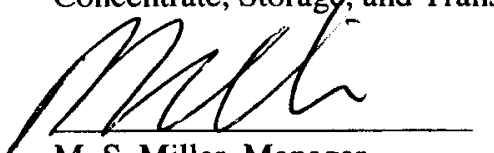

Date $2-1 /-02$

M. S. Miller, Manager

High Level Waste Division

Concentrate, Storage, Transfer Engineering

Materials Technology Section

Savannah River Technology Center 
WSRC-TR-2002-00065

\section{INTRODUCTION}

Radioactive wastes are contained in 48 underground storage tanks at the Savannah River Site (SRS). The materials and structures of the tanks provide a confinement function by maintaining leak integrity and structural stability. It is essential that the potential changes in properties of the structural materials due to service environment be evaluated and that conditions that can cause significant (active) degradation be avoided or mitigated. Aging mechanisms are those which cause changes in the materials including degradation of the materials. Degradation is either a reduction of the mechanical properties (e.g. loss of toughness or ductility), or a loss of net section of materials (e.g. cracking, pitting, thinning), or both which reduces the level of confinement inherent in the original installed condition and could lead to failure of confinement.

An assessment of the potential degradation mechanisms of Types I and II High-Level Waste (HLW) Tanks determined that pitting corrosion and stress corrosion cracking were the two most significant degradation mechanisms. Specifically, nitrate induced stress corrosion cracking was determined to be the principal degradation mechanism for the primary tank steel. ${ }^{1,2}$ Controls on the solution chemistry are in place to preclude the initiation and propagation of degradation in the tanks. However, recent experience has shown that steel not in contact with the bulk waste solution or slurry, but exposed to the "vapor space" above the bulk waste, may be vulnerable to the initiation and propagation of degradation, including pitting and stress corrosion cracking. Previous research has also determined that degradation is possible at the liquid-vapor interface (beach-line) due to inhibitor depletion.

There have been several recent examples of possible vapor corrosion. Photographs of Tank 15 taken between 1994 and 2000 of a portion of the middle girth weld region revealed an apparent through-wall crack (well above the dry sludge waste level in this particular tank). In Tanks 5 and 6 , previously unknown but probably pre-existing leak sites became evident by leakage into the annulus immediately after recent transfers of waste into those tanks. The recently observed Tank 5 and 6 leak sites were well above the pre-transfer waste level. Past leaks of radioactive waste from Type I and II tanks at SRS have been attributed to nitrate-induced stress corrosion cracking (SCC), with weld residual stresses providing the tensile stress field to drive cracking. This mechanism is believed responsible for the apparent crack in Tank 15, although ultrasonic testing has not yet been conducted to confirm the visual assessment. The Tank 5 and 6 leak sites have been attributed to nitrate induced SCC also, but visual examination alone of the painted Type I tanks cannot rule out pitting corrosion as another possible mechanism.

The Hanford Site also has had experiences indicating the possibility of vapor corrosion and beach-line corrosion. Photographs of certain double-shell HLW tanks at the Hanford Site have shown extensive general corrosion on the exterior of the primary wall due to rainwater inleakage. However, ultrasonic testing has shown wall thinning associated with corrosion of both the interior and exterior of the primary wall. Indications of internal corrosion were observed above the bulk waste level in one tank. Coupon testing has indicated that samples hung within the vapor space tend to degrade though the bulk solution is inhibited. 
WSRC-TR-2002-00065

\section{TECHNICAL APPROACH}

The approach to understand the vapor and beach-line corrosion will consist of four distinct phases:

1. Determining the relevant environments in the vapor space of the tanks.

2. Determining the material behavior in these environments.

3. Coupon testing in vapor space of tank.

4. Development of mitigation techniques of vapor corrosion, if found to occur.

The scope of this plan is limited to Phases 1 and 2. The results of the experimentation will be used to develop Phases 3 and 4.

The focus of the experimental investigation to date has been to attempt to reproduce crack growth in specimens of waste tank steel in the vapor above a sodium nitrate solution known to induce cracking. Tests on fatigue-pre-cracked ASTM A285 Grade C wedge-opening-loaded (WOL) specimens revealed crack growth in the sodium nitrate solution at $100^{\circ} \mathrm{C}$, but no growth in the vapor (at $\sim 85^{\circ} \mathrm{C}$ ) above the solution. No growth was seen even in a specimen that showed growth in the liquid phase before its removal to the vapor phase. Several factors may have contributed to SCC inhibition. The experimental technique allowed the specimens to dry each time they were measured for crack growth. This drying may have allowed a protective oxide film to inhibit SCC. Another factor that may have contributed to the inhibition or prevention of SCC was the high general corrosiveness of the vapor environment. Specimens in the vapor phase readily condensed the $100 \%$ relative humidity $(\mathrm{RH})$ vapor in the sealed test vessels, and considerable general corrosion resulted from the condensation.

Stress corrosion cracking is unlikely to occur under active corrosive conditions. SCC requires the steel to be in an electrochemical range termed the active-passive transition. SCC exists under conditions that are generally protective of the greater part of the metal surface, with metal oxidation occurring only at the crack tip, but not along the passive walls of the crack. In a generally corrosive electrochemical environment, the aqueous metal ion is thermodynamically stable until it reacts with water, and no protective oxide layer forms and thus no part of the metal is passive. In a locally corrosive environment an oxide layer (of varying degrees of protectiveness) is thermodynamically favored, but is unstable due to the action of small concentrations of aggressive species, such as nitrate (on carbon steel) or chloride (on stainless steel).

\section{ENVIRONMENTAL CONDITIONS}

\subsection{Vapor Corrosion Mechanism}

It is hypothesized that a crack may propagate in the vapor space environment of a waste tank in the special conditions created by relative humidity and the deliquescence behavior of aggressive species. Specifically, sodium nitrate salt is assumed to be present on the wall and cooling coils of waste tanks. Several mechanisms have been proposed for the deposition of aggressive species on the tank wall within the vapor space. In dry environments the salt may exist as a solid residue 
on the steel tank, left by evaporation or decanting of supernate. Alternatively, sodium nitrate may have been deposited on the tank wall by evaporation from the supernate, transport as an aerosol, and then condensation on the tank wall. In sufficiently humid conditions the nitrate residue can adsorb atmospheric moisture and dissolve, forming a corrosive electrolyte.

In the first mechanism, it is hypothesized that a corrosive, nitrate-rich liquid electrolyte existed at the initiation site and within the propagating crack. The electrolyte first could have been present upon filling the tank with insufficiently inhibited waste. During the initial period of operation, prior to the institution of chemistry controls, the crack could have initiated, grown to a certain depth and then ceased growth due to inhibition of the waste. The supernate evaporated leaving salt deposits on the surface of the remaining sludge and on the steel walls. These deposits would deplete in hydroxide over time due to reaction with atmospheric carbon dioxide. Under wet conditions caused by the irregular operation of the purge ventilation of the tank vapor space, the deposits could re-dissolve to create a nitrate-rich electrolyte that could restart cracking. The tensile stress may be provided by the wedge action of the aggressive species within the crack.

The alternate hypothesis is that an aqueous solution in-tank can lead to the deposition of the salts on the tank wall in the vapor space through an aerosol transport process. The mutual deliquescence relative humidity (MDRH) plays a role in determining the precipitation sequence of the salts as a function of relative humidity. The deliquescence point of sodium nitrate at room temperature has been reported to be $74 \%{ }^{3}$ However, the MDRH of a mixture of salts is generally lower than the deliquescence point of the single salts indicating the transition to a completely liquid system and the sequential dissolving of the electrolytes. It is known that the eutectic composition of the liquid phase and the MDRH are constant for all ratios of salt. The eutectic point is defined to be the point at which the solution has become saturated with all salts, and the relative humidity is deemed the MDRH. As the relative humidity is reduced, the precipitation sequence of the salts may be different dependent upon the mixture and thermodynamic properties. In terms of the Gibbs' Phase Rule, at a specific temperature and pressure, there are no degrees of freedom, and the eutectic point is fixed and invariant irrespective of the total amounts of salt present.

Diurnal variation in the relative humidity may alternately dissolve and crystallize sodium nitrate, especially in the summer, when morning air is near saturation $(100 \% \mathrm{RH})$ and afternoon heating lowers the RH below $60 \%$. This cyclic exposure may render the steel more vulnerable than it might be under static conditions, as the cyclic exposure may tend to build up high nitrate concentrations, depending on the precipitation sequence. Aggressive general corrosion, which has never been detected in SRS high-level waste tanks, requires higher humidity conditions or wet conditions, such as have existed apparently for long periods in certain waste tanks at the Hanford Site that have experienced substantial ( 20\%) wall thinning.

It may be assumed the relative humidity of the vapor space is maintained at atmospheric humidity due to the purge ventilation systems. The HLW tanks are equipped with a purge ventilation system to maintain the tank contents at negative pressure to prevent the release of radioactive material into the environment. The purge ventilation is run continuously at 300 cubic feet per minute to ensure that the buildup of flammable vapor concentration remains below a critical level. However, outages of purge ventilation systems are allowed within the time frames in HLW Tank Farm Technical Safety Requirements (TSRs). 
The humidity data for the months of March-June 2000 is shown in Figures 1 through 4. It is seen that the relative humidity cycles about the deliquescence point of sodium nitrate and most probably the MDRH for a mixture of sodium nitrate, sodium nitrite, and sodium hydroxide. Such cycling may contribute to the deposition of a concentrated aggressive species on the tank wall.

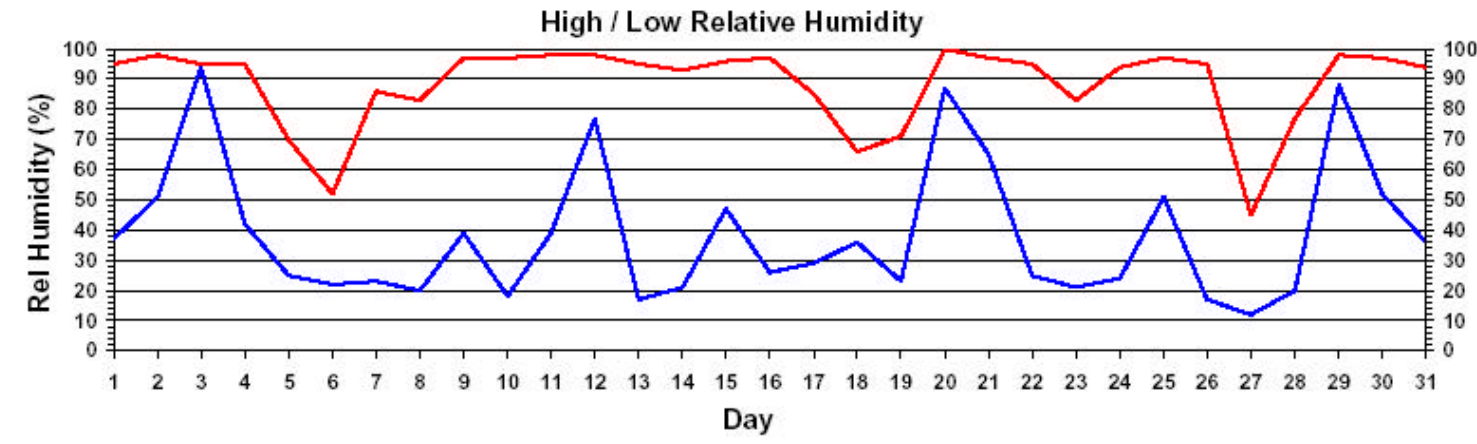

Figure 1: Atmospheric Humidity for Month of March 2001.

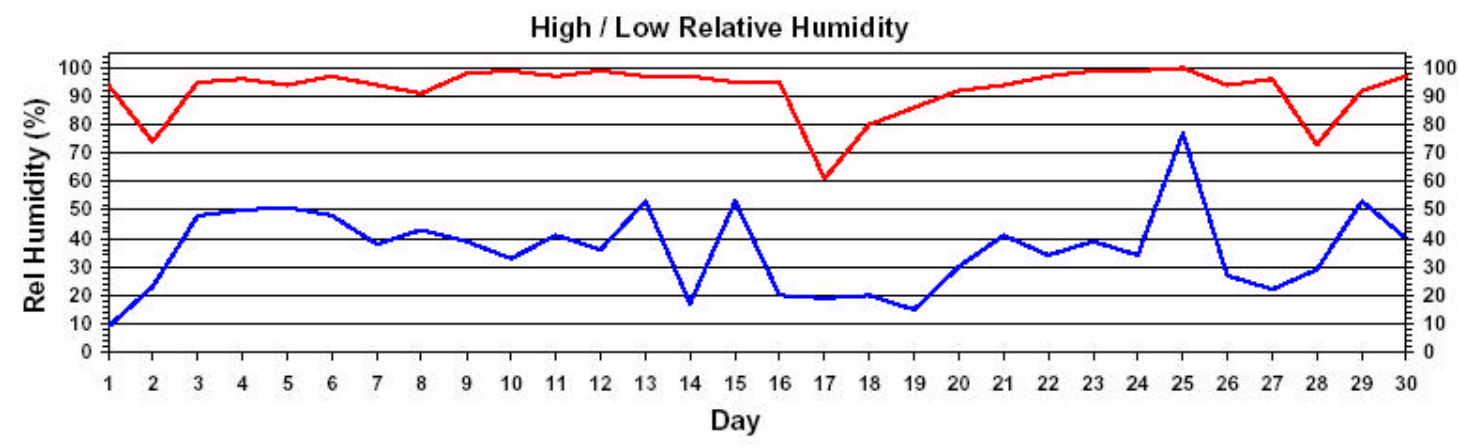

Figure 2: Atmospheric Humidity for Month of April 2001.

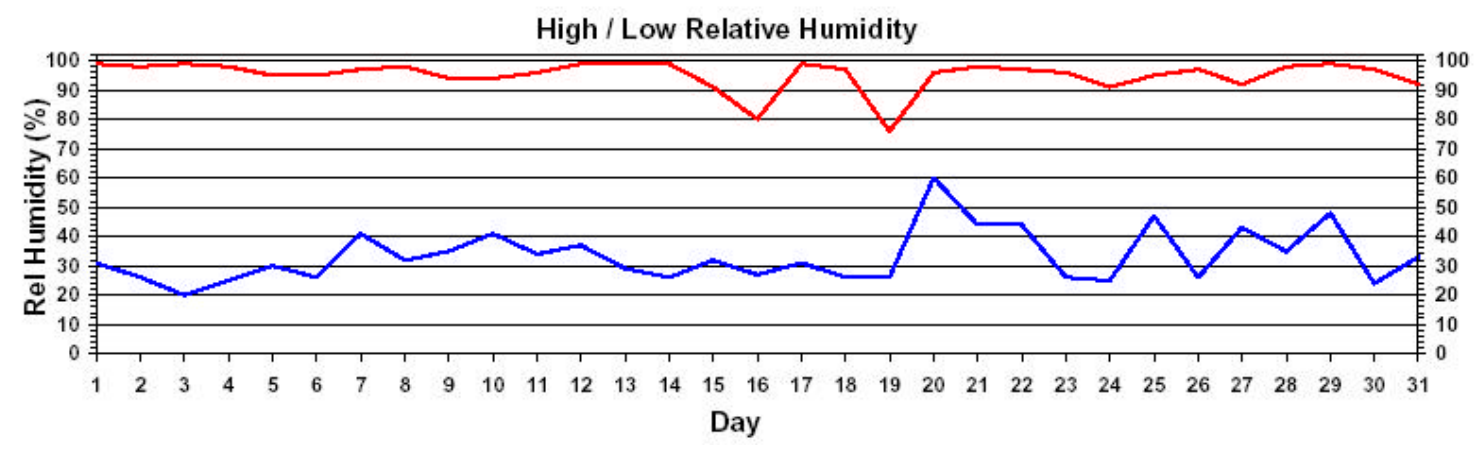

Figure 3: Atmospheric Humidity for Month of May 2001. 


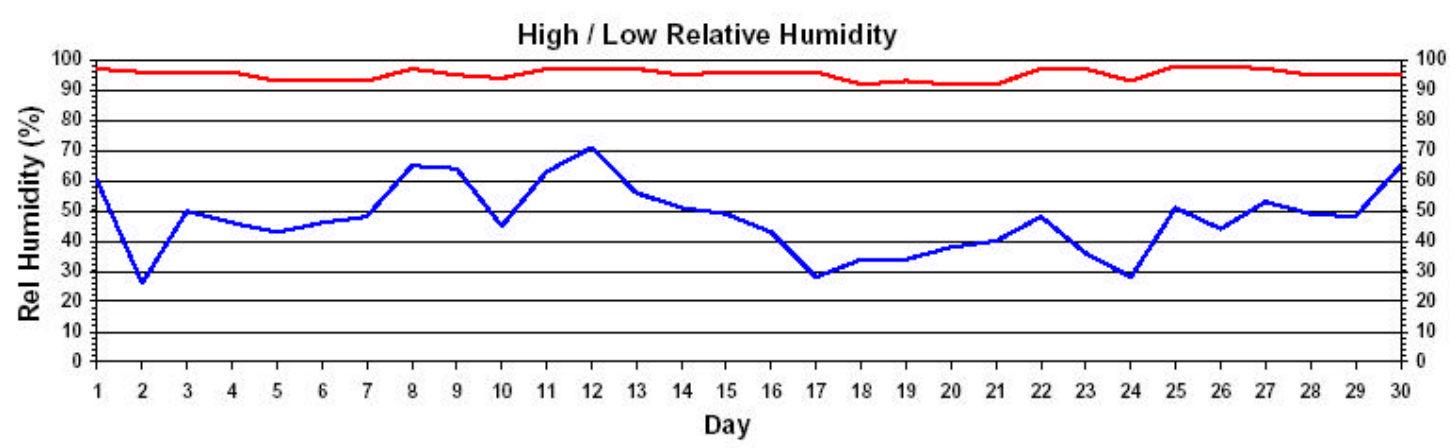

Figure 4: Atmospheric Humidity for June 2001.

\subsection{In-Service Vapor Space Chemistry ${ }^{4}$ (reproduced from Reference 4)}

The apparent Tank 15 crack grew in the absence of a bulk electrolyte. As part of the corrosion assessment of the Tank 15 crack, samples of the vapor space of Tank 12 and Tank 15 have been taken to determine concentration of nitrate within the vapor space for comparison purposes. The Tank 12 vapor space concentration was calculated by using HEPA filter core sample data. ${ }^{5}$ The Tank 12 HEPA filter obtained for sampling had approximately 15 million cubic feet of air passed through it during its two-year service operation. A core sample was taken from the filter for analysis and was divided into four sub-samples. The vapor space nitrate concentration was calculated using two methods: averaging all four sub-section nitrate concentrations and using the highest nitrate concentration core sub-section (filter inlet sub-section). The nitrate concentration of the air in the Tank 15 vapor space was estimated by comparing Tank 12 HEPA filter results in a ratio to the nitrate concentration from Tank 15 and Tank 12 HEPA ventilation plenum smears. ${ }^{6}$ Table 1 details the results. The results indicate that the nitrate concentration within the vapor space of Tank 15 is much higher than that of the Tank 12 nitrate concentration.

Table 1: Nitrate Concentration of Tank 12 and Tank 15 Vapor Spaces

\begin{tabular}{|c|c|c|c|}
\hline & $\begin{array}{c}\mathrm{NO}_{3} \\
(\boldsymbol{\mu g} / \mathrm{filter})\end{array}$ & $\begin{array}{c}\text { Tank 12 }(\boldsymbol{\mu g} \\
\left.\mathrm{NO}_{\mathbf{3}} / \mathbf{f t}^{\mathbf{3}}\right)\end{array}$ & $\begin{array}{c}\text { Tank 15 }(\boldsymbol{\mu g} \\
\left.\mathbf{N O}_{\mathbf{3}} / \mathbf{f t}^{\mathbf{3}}\right)\end{array}$ \\
\hline $\begin{array}{c}\text { Average } \mathrm{NO}_{3} \\
\text { Conc. }\end{array}$ & 3705.75 & 1.12 & 2.49 \\
\hline $\begin{array}{c}\text { Highest } \mathrm{NO}_{3} \\
\text { Conc. }\end{array}$ & 6000 & 1.81 & 4.03 \\
\hline
\end{tabular}

Evidence indicates that the relative humidity in Tank 15 is extremely high. In addition, partially ground out seam welds indicate possible moisture accumulation sites along horizontal welds.

\subsection{Liquid-Vapor Interface Environment and Degradation}

At the vapor-liquid interface, caustic solution $\mathrm{pH}$ will drop naturally over a period of a few months to $\mathrm{pH} 10$ due to chemical reaction of the hydroxide with atmospheric carbon dioxide. 
The shift in $\mathrm{pH}$ makes this interface region vulnerable to pitting corrosion and possibly crevice corrosion. Mechanistically, aggressive anion concentration cells may develop at stagnant vapor/liquid interfaces to accelerate corrosive attack. This type of attack is also known as waterline or beach-line attack. Oxygen concentration cells may develop as oxygen is readily available at the vapor/liquid interface, but has increasingly restricted access to levels more distant from the surface. The concentration gradient anodically polarizes the area of the tank wall slightly below the surface. This polarization leads to preferential dissolution of tank wall material at this area. Dissolved metal can then react with hydroxide, which is cathodically produced at the liquid/vapor interface, to form corrosion products that precipitate just below the water line. These deposits further retard the diffusion of oxygen and accelerate the dissolution of the tank metal. In tanks with constant waste levels, pitting corrosion could be a severe source of degradation. Previous research has shown that the inhibitor depletion at the liquid-vapor interface could lead to attack. The experimentation detailed herein would be used to validate and augment those results.

\section{EXPERIMENTATION}

Experimentation to analyze the vapor corrosion phenomena will consist of two stages:

1. Determine thermodynamic behavior of solutions containing a mixture of sodium nitrate, sodium nitrite, and sodium hydroxide.

2. Determine material behavior in relevant environmental conditions.

\subsection{Thermodynamic Behavior}

Experimentation to determine the vapor space environment will lend a thermodynamic basis to the possibility of the occurrence of the vapor space corrosion phenomenon. The thermodynamic behavior of $\mathrm{NaNO}_{3}, \mathrm{NaNO}_{2}$, and $\mathrm{NaOH}$ solutions will be determined. Nitrate and hydroxide concentrations are maintained within the tank as the inhibitor species. Condensation experiments will be done to determine the electrolyte concentration of the vapor space. The test cell will contain a solution reservoir and will be placed within an oven (Figure 5). The test cells are equipped with condensers supplied with re-circulated chilled water and a condensate reservoir. The condensate will be analyzed for electrolyte concentration. Experimentation will be performed at $50^{\circ} \mathrm{C}$ and boiling solution. The volatility of the solution and consequent aerosolization of the salts will be thus determined. 


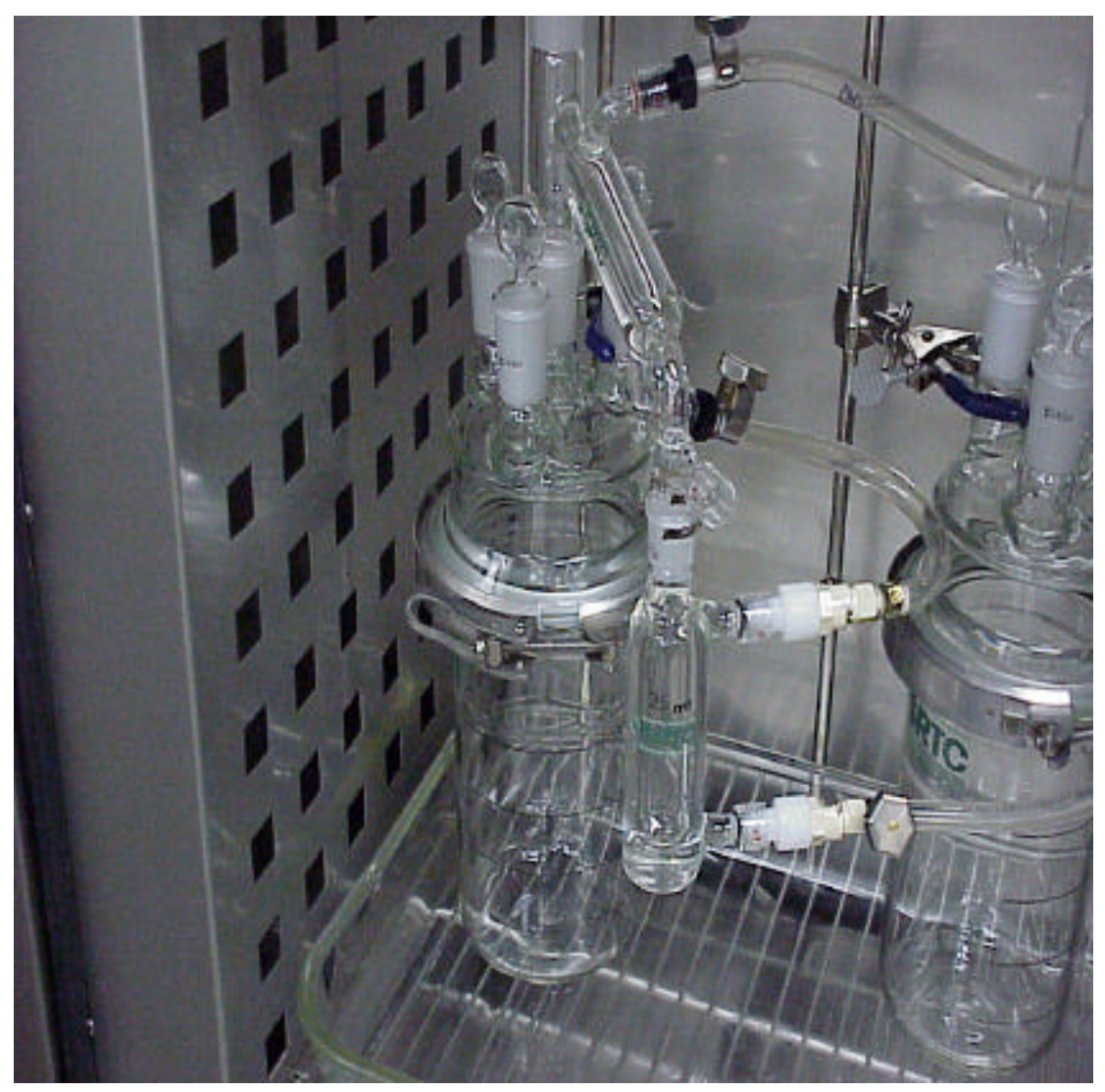

Figure 5: Condensation Experiment Test Cells in Oven.

Once the concentrations within the vapor space are determined, the results may be used to model deposition of species on the tank wall. The deposition sequence may determine whether an inhibited bulk solution effectively controls degradation in the vapor space.

The specific solutions to be tested are detailed in Table 2. The anions concentrations fall within the Technical Safety Requirements (TSR) for corrosion control, except for the aggressive solution containing only $5 \mathrm{M} \mathrm{NO}_{3}{ }^{-}$, which is uninhibited and assumed to be the most corrosive ${ }^{7}$ The results will be used to determine whether vapor space chemistries favor or inhibit corrosion processes. The chemistry within the reservoir will be periodically measured to determine solute depletion. However, the mixture will not be replenished.

Table 2: Waste Chemistries for Experimentation

\begin{tabular}{cccc}
$\#$ & $\mathrm{NO}_{3}^{-}$ & $\mathrm{NO}_{2}^{-}$ & $\mathrm{OH}^{-}$ \\
\hline $\mathrm{W} 1$ & 5 & - & - \\
$\mathrm{W} 2$ & 7.5 & 0.5 & 0.6 \\
$\mathrm{~W} 3$ & 1.5 & 0.45 & 0.15
\end{tabular}


WSRC-TR-2002-00065

\subsection{Material Behavior}

The general corrosion response and the SCC susceptibility of the steel in relevant environmental conditions will be established. The test environment to induce the vapor space cracking must promote localized corrosion but largely inhibit substantial general or uniform corrosion. In previous testing, a 100\% relative humidity vapor caused extensive general corrosion of steel, sufficient to cover with rust the fatigue pre-crack of a WOL specimen. As a result, the WOL specimen was passivated with rust and further microscopic determination of crack growth was hindered. Controlling humidities below saturation seems necessary to create SCC conditions. The planned SCC testing will involve testing in sub-100\% RH humidity conditions above and below the deliquescence point of sodium nitrate.

The general corrosion, pitting, and stress corrosion cracking response of ASTM A285 and ASTM A537 steel will be studied. The test cell shown in the Figure 6 will be used to evaporate the solutions of the above mentioned chemistries on coupons made of ASTM A537 and ASTM A285 at $50^{\circ} \mathrm{C}$. Three types of coupons will be tested: (1) polished (1200 grit), (2) mill-scale, and (3) as-machined.

Constant condition and cyclic condition tests will be done. The constant conditions will be as follows: $50^{\circ} \mathrm{C}, 50 \%$ relative humidity, and greater than $95 \%$ relative humidity. Tests done under cyclical relative humidity conditions will be done by ventilating the vapor space of the test cell with ambient outside air. Ambient atmospheric air will best simulate the purge ventilation system of the HLW tanks. Tests will be run for 50 and 100 days, to allow for measurement of growth rates, if corrosion is found. The following table summarizes the test matrix variable parameters.

\section{Table 3: Test Matrix Variables for Experimentation}

\begin{tabular}{ccccc} 
& Materials & Material Finish & Humidity & Duration \\
\hline $\mathbf{1}$ & ASTM A285 & $\begin{array}{c}\text { Polished (1200 } \\
\text { grit) }\end{array}$ & $50 \%$ & 50 days \\
$\mathbf{2}$ & ASTM A537 & Mill-scale & $>95 \%$ & 100 days \\
$\mathbf{3}$ & & As-machined & Cyclic &
\end{tabular}

(* All testing will be done at $50^{\circ} \mathrm{C}$.)

Corrosion testing will be done within the test cells shown in Figure 6. Each of the test cells has a liquid reservoir and 3 ports for instrumentation and ventilation to control humidity.

Susceptibility to general corrosion, pitting, and stress corrosion cracking will be determined. General and pitting corrosion will be studied in a parametric test matrix with the aforementioned parameters. SCC testing will be limited to as-machined steel at constant and cyclic humidity. Several polished specimens will be done to validate effects of surface finish. The test matrix, in its entirety, is shown in the Appendix. The following sections outline test procedures for each. 


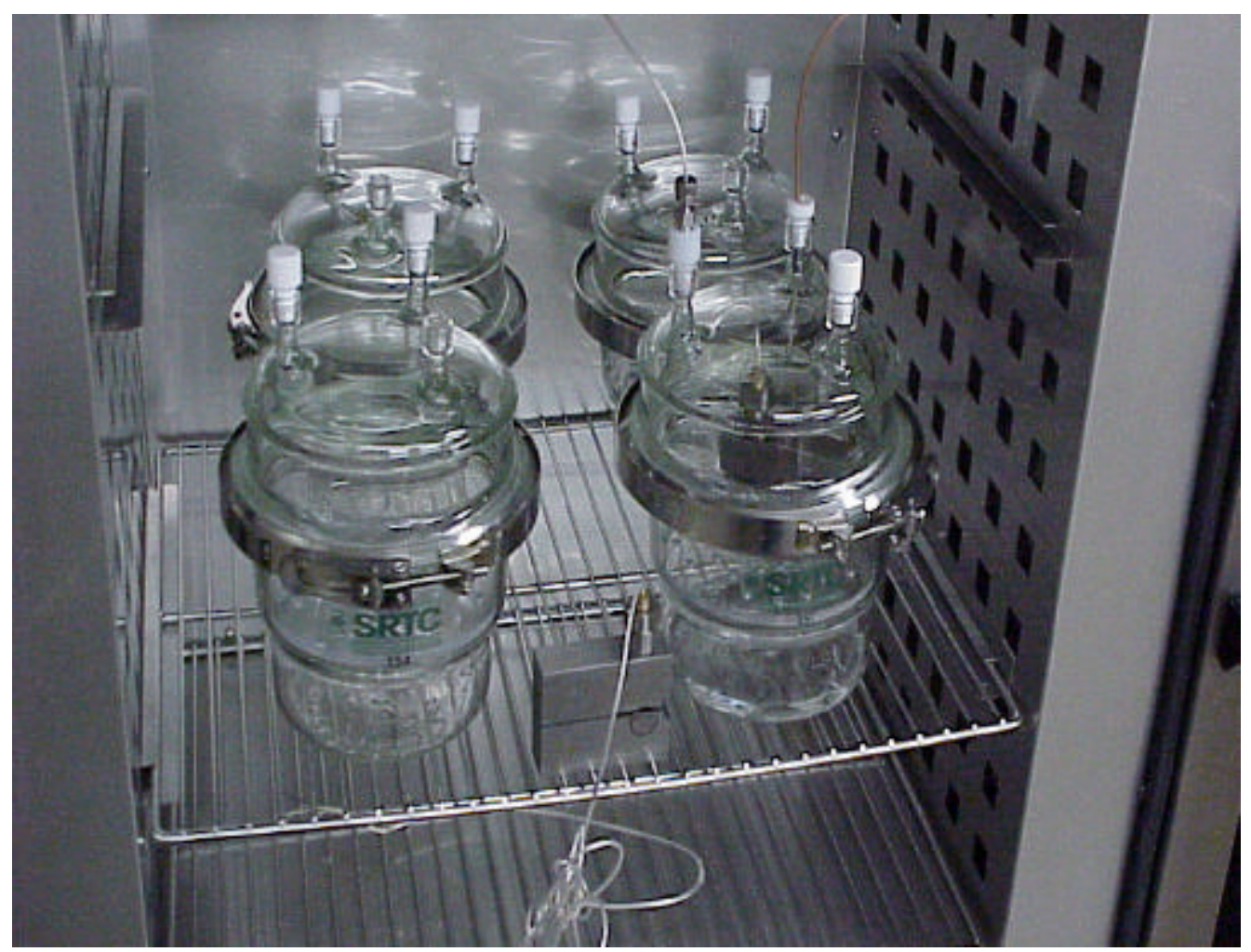

Figure 6: Vapor Corrosion Test Cells. Instrumented WOL Specimen.

\subsection{Pitting Corrosion/General Corrosion}

There is a possibility of pitting and general corrosion existing in the vapor space at the conditions detailed within the Appendix. Partial immersion tests of W2, and W3 will be done as shown in the Appendix to determine the beach-line corrosion behavior.

Coupons will be evaluated for pitting corrosion using guidelines outlined by ASTM Standard G46, "Standard Guide for Examination and Evaluation of Pitting Corrosion." The following is an outline of the procedure as it will be used to evaluate pitting, if found, in the tests coupons.

Pits will be identified and examined visually. The surface (with the corrosion product) will be examined under ordinary light and photographed at a low power magnification. Following procedures outlined in NACE Standard RP-01-73, the surface will be cleaned and the removed corrosion products will be identified. The cleaned metal surface will again be examined under ordinary light and photographed under microscopic magnification of 20x. The cleaned surface will be compared to photographs taken of the surface with the corrosion product.

The size, shape, and density of pits will be determined. The material surface will be systematically partitioned using a grid, and each section will be photographed at low magnification. Image analysis software will be used to determine the cumulative density of pits, as well as localized density of pits relative to coupon.

The coupon will be metallographically examined to determine extent of pitting, and the relationship between pits, inclusions, and the microstructure. The extent of pitting will also be 
metallographically determined. Pit depth will be determined by sectioning vertically through a pre-selected pit, mounting, and polishing the surface. The pit will be photographed and the depth of the pit will be optically measured. Mass loss will be measured to provide information about total metal loss, but will not indicate depth of penetration.

Pitting will be rated in terms of density, size, and depth on the basis of the standard charts provided by ASTM G46. Metal penetration will be reported as the average depth of the 10 deepest pits that are measured. Metal penetration will also be expressed in terms of a pitting factor, defined as the ratio between deepest metal penetration over the average penetration.

\subsection{Stress Corrosion Cracking (SCC)}

SCC testing will be done using an instrumented wedge-opening loaded (WOL) specimen to provide continuous exposure data. Instrumented specimens have loading bolts that are furnished with a strain gage that continuously monitor load from which stress intensity factor can be calculated.

\subsubsection{WOL Specimen}

The WOL specimens will be machined from the plate in the T-L orientation. The specimens are of standard dimension: $0.97 \mathrm{in}$. thickness, $2.55 \mathrm{in}$. net width, and notch depth of $0.75 \mathrm{in}$. The specimens were side-grooved and chevron notched to ensure flat front crack growth. The specimens will be bolt loaded. In this procedure the pre-crack is opened by tightening a bolt to a specified distance, which is maintained constant throughout testing. An crack opening displacement (COD) gage will be used to measure the displacement.

In the course of testing, an initial pre-crack will grow under the driving force of the initial applied stress intensity, until growth decreases the applied stress intensity below a threshold or critical value, at which point growth is arrested. The critical stress intensity factor $\left(\mathrm{K}_{\mathrm{ISCC}}\right)$ can be calculated from the length of the crack at arrest. The desired initial stress intensity factor $\mathrm{K}_{\mathrm{I}}$ was

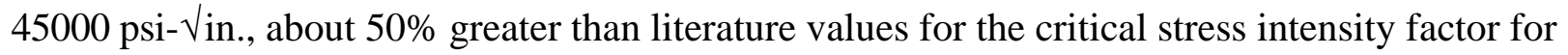
nitrate-induced stress corrosion cracking. This step will be conducted in the absence of the corrosive solution.

\subsubsection{Stress Intensity Measurement}

The direct load drop will be measured and the crack length calculated using published compliance relationships for compact tension specimens. The non-dimensional load-line compliance solution for a through-thickness crack in a flat plate is shown in Equation 1, with the component relationships shown in Equations 2 through 4.

$$
Z_{L L}=\frac{\Delta B_{e} E^{\prime}}{P}=\left(\frac{1+\frac{a}{w}}{1-\frac{a}{w}}\right)^{2}\left[2.163+12.219\left(\frac{a}{w}\right)-20.065\left(\frac{a}{w}\right)^{2}-0.9925\left(\frac{a}{w}\right)^{3}+20.609\left(\frac{a}{w}\right)^{4}-9.9314\left(\frac{a}{w}\right)^{5}\right]
$$

where: $\Delta=$ Displacement (shown in Equation 2)

$\mathrm{B}=$ Thickness (effective thickness shown in Equation 3 for side-grooved specimens) 


$$
\begin{aligned}
& E^{\prime}=\text { Elastic modulus } \\
& a=\text { Crack length } \\
& \text { w = Width }
\end{aligned}
$$

\section{Equation 1: Non-Dimensional Load-Line Compliance for Through Thickness Cracks in Flat Plates}

$$
\Delta=\Delta_{c}+\Delta_{n c}
$$

where: $\quad \Delta_{\mathrm{c}}=$ Displacement due to crack

$\Delta_{\mathrm{nc}}=$ Displacement in the absence of a crack at a given load.

Equation 2: Total Displacement

$$
B_{e}=B-\frac{\left(B-B_{N}\right)^{2}}{B}
$$

Equation 3: Effective Thickness where $B_{N}$ is the Net Thickness

$$
E^{\prime}=\frac{E}{\left(1-v^{2}\right)}
$$

\section{Equation 4: Elastic Modulus}

The load drop measured will be used to calculate a compliance, after which the crack length will be solved iteratively for a given load. Once the crack length is established Equation 5 will be used to calculate the stress intensity. The compliance function ' $\mathrm{f}(\mathrm{a} / \mathrm{w})$ ' is given in Equation 6 .

$$
K_{I}=\frac{P \cdot f\left(\frac{a}{w}\right)}{B \sqrt{W}}
$$

Equation 5: Stress Intensity for Compact Tension Specimen

$$
f\left(\frac{a}{w}\right)=\frac{2+\frac{a}{w}}{\left(1-\frac{a}{w}\right)^{\frac{3}{2}}}\left[0.886+4.64\left(\frac{a}{w}\right)-13.32\left(\frac{a}{w}\right)^{2}+14.72\left(\frac{a}{w}\right)^{3}-5.6\left(\frac{a}{w}\right)^{4}\right]
$$

\section{Equation 6: Compliance Functions Solutions for Compact Tension Specimen}

The stress intensity will be calculated and ultimately the $\mathrm{K}_{\mathrm{ISCC}}$ will be reported. $\mathrm{K}_{\mathrm{ISCC}}$ is the stress intensity factor above which SCC will initiate and grow for the specified condition 
(material, environment, exposure time, etc.), under predominantly plane strain conditions.

\section{APPLICATION OF RESULTS}

The proposed Phase 1 and 2 laboratory tests are intended to reveal the extent and severity of the modes of vapor space and beach-line corrosion in the HLW tank environment. Any findings of corrosive degradation in the laboratory tests should be confirmed in additional coupon tests that may include in-tank exposures (Phase 3). Cost-effective mitigation or prevention of the degradation may be developed and demonstrated in additional experiments, if necessary (Phase 4).

Confirmatory results of the testing will be used to develop mechanistic understanding of the vapor space phenomena within Tank 15, and possibly other tanks that have exhibited the same phenomenon within the DOE complex. The thermodynamic behavior understanding may lend a basis for the aerosol transport hypothesis for species deposition. The experimentation will determine whether the relative humidity cycling is such that once the deposition occurs, the aggressive species become concentrated at the appropriate locations in the vapor space. 
WSRC-TR-2002-00065

\section{REFERENCES}

${ }^{1}$ Costas, L. P., Holzworth, M. L., Rion, W.C., "Stress Corrosion Cracking of Carbon Steels in Simulated Waste Solutions," DP-1023, June 1966.

2 Poe, W. L., "Leakage from Waste Tank 16: Amount, Fate, and Impact,” DP-1358, November 1974.

${ }^{3}$ Farmer, J. F., McCright, R. D., "General Corrosion and Localized Corrosion of Waste Package Outer Barrier,” ANL-EBS-MD-000003, Lawrence Livermore National Laboratory, January 2000 .

${ }^{4}$ Strong, L. A., “Assessment of Environmental Conditions in the Tank 15 Vapor Space," WSRCTR-99-00412, December 1999.

${ }^{5}$ Ekechukwu, A. A., “Technical Report: Analysis of Tank 12-H HEPA Filter,” WSRC-TR-9900035 , January 1999.

${ }^{6}$ Ekechukwu, A. A., “Technical Report: Analysis of Tank 12 and 15 Vapor and Smear Samples,”WSRC-TR-98-00318, December 1998.

7 "TSR Administrative Control Compliance Requirements, Corrosion Control Program," GTRT-G-00003, Appendix 6 Rev. 7, Westinghouse Savannah River Company, Aiken, SC, June 2000 .

${ }^{8}$ Anderson, T. L., Fracture Mechanics, $2^{\text {nd }}$ Ed., CRC Press, 1995. 


\section{APPENDIX: TEST MATRIX}

Pitting/General Corrosion: Vapor Space

\begin{tabular}{|c|c|c|c|c|}
\hline Chemistry & Steel & Finish & Humidity & Duration \\
\hline \multirow[b]{8}{*}{$\mathrm{W} 1$} & \multirow{18}{*}{$\begin{array}{l}\text { ASTM A285 } \\
\text { ASTM A537 }\end{array}$} & Finely Polished & $50 \%$ & 50 days \\
\hline & & Mill Scale & $50 \%$ & 50 days \\
\hline & & As-Finished & $50 \%$ & 50 days \\
\hline & & Finely Polished & $>95 \%$ & 50 days \\
\hline & & Mill Scale & $>95 \%$ & 50 days \\
\hline & & As-Finished & $>95 \%$ & 50 days \\
\hline & & Finely Polished & $50 \%$ & 100 days \\
\hline & & Mill Scale & $50 \%$ & 100 days \\
\hline \multirow{10}{*}{$\begin{array}{l}\text { W2 } \\
\text { W3 }\end{array}$} & & As-Finished & $50 \%$ & 100 days \\
\hline & & Finely Polished & $>95 \%$ & 100 days \\
\hline & & Mill Scale & $>95 \%$ & 100 days \\
\hline & & As-Finished & $>95 \%$ & 100 days \\
\hline & & Finely Polished & Cyclical & 50 days \\
\hline & & Mill Scale & Cyclical & 50 days \\
\hline & & As-Finished & Cyclical & 50 days \\
\hline & & Finely Polished & Cyclical & 100 days \\
\hline & & Mill Scale & Cyclical & 100 days \\
\hline & & As-Finished & Cyclical & 100 days \\
\hline
\end{tabular}


Pitting/General Corrosion: Liquid-Vapor Interface

\begin{tabular}{|c|c|c|c|}
\hline Chemistry & Steel & Finish & Duration \\
\hline \multirow{4}{*}{ W2 } & & Finely Polished & 50 days \\
\cline { 3 - 4 } W3 & \multirow{4}{*}{ ASTM A285 } & Mill Scale & 50 days \\
\cline { 3 - 4 } & ASTM A537 & As-Finished & 50 days \\
\cline { 3 - 4 } & & Finely Polished & 100 days \\
\cline { 3 - 4 } & & Mill Scale & 100 days \\
\cline { 3 - 4 } & & As-Finished & 100 days \\
\hline
\end{tabular}


WSRC-TR-2002-00065

Stress Corrosion Cracking

\begin{tabular}{|c|c|c|c|c|}
\hline Chemistry & Steel & Finish & Humidity & Duration \\
\hline \multirow{2}{*}{ W1 } & & & $50 \%$ & 50 days \\
\cline { 4 - 5 } & & & $>95 \%$ & 50 days \\
W2 & ASTM A285 & Polished & $50 \%$ & 100 days \\
\cline { 4 - 5 } & & $(1200$ grit $)$ & $>95 \%$ & 100 days \\
\cline { 4 - 5 } & & & Cyclical & 50 days \\
\cline { 4 - 5 } & & & Cyclical & 100 days \\
\hline
\end{tabular}

